\title{
SUITABILITY OF THE REMEDY OF DIVESTITURE IN NON-MERGER CASES: A SOUTH AFRICAN PERSPECTIVE
}

\author{
Phumudzo S Munyai \\ LLB LLM LLD \\ Associate Professor, Department of Private Law, \\ University of Pretoria
}

\section{SUMMARY}

This article considers the suitability of the remedy of divestiture in non-merger cases, particularly in markets where high concentration levels may embolden incumbents to engage in abusive conduct. The article observes that the prevailing practice in competition-law enforcement is that, while divestiture is an acceptable remedy in merger cases, it is generally eschewed in non-merger cases. The article argues that economic conditions in South Africa provide justification for the use of the divestiture remedy in non-merger cases, particularly in cases of abuse of dominance in concentrated markets. The article observes that there is sufficient legal authority and history supporting the use of the remedy in non-merger cases.

\section{INTRODUCTION}

After two and a half decades of the South African democratic experiment, it may be appropriate to review the effectiveness of some of the policy tools and legal instruments that were introduced to improve the social and economic welfare of citizens. At the end of apartheid, among the most pressing economic problems (at least to the incoming ANC government and the majority of those disadvantaged by policies of the past) were the racially skewed patterns of ownership of the productive assets of the economy and anticompetitive market structures that were characterised by economic concentration. ${ }^{1}$ Economic concentration refers to the extent to which a small number of firms account for the bulk of sales in a given market. ${ }^{2}$ In simple

\footnotetext{
OECD "Competition Law and Policy in South Africa: An OECD Peer Review" (May 2003) https://www.oecd.org/daf/competition/prosecutionandlawenforcement/2958714.pdf (accessed 2020-04-08) 10; Roberts "The Role for Competition Policy in Economic Development: The South African Experience" (June 2004) https://www.tips.org.za/researcharchive/trade-and-industry/centre-for-real-economy-study-crest/item/385-the-role-forcompetition-policy-in-economic-development-the-south-african-experience (accessed 202004-08) 1-2.

2 See Competition Amendment Bill 2017 GN 1345 in GG 41294 of 2017-12-01 7.
} 
terms, it is the accumulation of market and economic power in the hands of a few firms.

At the beginning of the democratic era, high on the agenda of the new ANC-led government was a strong competition policy system, complete with strong legislation and institutions that were expected to hit the ground running in addressing historical imbalances in the structure of the economy. ${ }^{3}$ However, more than 20 years after the coming into force of the Competition Act, ${ }^{4}$ the problem of concentration in the economy has remained, ${ }^{5}$ if not worsened. By the same token, collusive and abusive conduct by firms in concentrated markets has not abated. ${ }^{6}$

There is broad consensus in the competition policy and law community that highly concentrated markets provide the ideal environment for collusion and abuse of dominance to take place. ${ }^{7}$ Therefore, highly concentrated markets provide the perfect justification for competition policy and law intervention to ensure that there is competition in such markets. In cases of abuse of dominance, particularly in highly concentrated markets, there may be need for competition authorities to be bolder and more interventionist in designing competition-law remedies, ${ }^{8}$ particularly where other remedies may be less effective.

3 OECD https://www.oecd.org/daf/competition/prosecutionandlawenforcement/2958714.pdf 9 . The Reconstruction and Development Programme (RDP) policy document, for example, proposed that strict antitrust legislation was needed in the country, systematically to eliminate the high market concentration levels that existed in South Africa; see White Paper on Reconstruction and Development GN 1954 in GG 16085 of 1994 par 3.8.1.

489 of 1998.

5 Following a study of about 2150 merger reports of the Competition Commission between January 2009 and March 2016, Buthelezi, Mtani and Mncube observe that at least 70,45\% of South African sectors have defined markets with dominant firms, which - according to them - indicates the static level of market concentration in the South African economy. That the majority of South African sectors are concentrated, the authors further observe, also accords with various studies that have been conducted on the concentration levels of South African industries; see Buthelezi, Mtani and Mncube "The Extent of Market Concentration in South Africa's Product Markets" (2018) https://www.ellipsis.co.za/wpcontent/uploads/2018/09/The-extent-of-market-concentration-in-South-Africa's-productmarkets-CC-Working-Paper.pdf 3.

6 In the 2018-2019 financial year, the Competition Commission received between 252 and 256 complaints relating to cartels and abuse of dominance. During this period, the Commission was also involved in litigation in some 138 cases relating to cartels and abuse of dominance; see Competition Commission of South Africa "Annual Report" (2018-2019) http://www.compcom.co.za/wp-content/uploads/2019/10/Annual-Report-2018-2019.pdf 2432.

7 This is in line with the Structure-Conduct-Performance paradigm, which, in its simplest form, holds that the structure of the market dictates the conduct of firms, which in turn dictates performance (Buthelezi, Mtani and Mncube https://www.ellipsis.co.za/wpcontent/uploads/2018/09/The-extent-of-market-concentration-in-South-Africa's-productmarkets-CC-Working-Paper.pdf 3). The trend towards concentration and oligopoly, it has been observed, raises a serious threat to the maintenance of properly functioning and competitive markets (Scala "Advertising and Shared Monopoly in Consumer Goods Industries" 19739 Columbia Journal of Law and Social Problems 241 241-245). See also Sullivan "The Jurisprudence of Antitrust Divestiture: The Path Less Travelled" 200286 Minnesota Law Review 565572.

8 O'Connor "The Divestiture Remedy in Sherman Act 2 Cases" 197613 Harvard Journal on Legislation 687 691; Scala 1973 Columbia Journal of Law and Social Problems 242. 
The Competition Act $^{9}$ provides a number of mechanisms for competition authorities to use in dealing with the problem of concentration in the economy as well as with the resultant collusive and abusive practices. Among such mechanisms is the remedy of divestiture. With divestiture, sometimes loosely referred to as "break-up", ${ }^{10}$ a firm (usually one with substantial market share) is ordered to disinvest or sell its shares or assets in a given market. ${ }^{11}$ Following divestiture, the hope is that the market will become free and open to entry and expansion by other firms, thereby facilitating much-needed competition.

This article considers the suitability of the remedy of divestiture in repeat or serious abuse of dominance cases, particularly in concentrated markets and where there is no better alternative remedy. The article also considers the suitability of the remedy of divestiture in circumstances where, as recent amendments to the Competition Act suggest, ${ }^{12}$ the Competition Commission (after the conclusion of a market enquiry) finds that the structure of the market (in particular, the concentrated or oligopolistic nature of such market) has or is likely to have an adverse effect on competition in the market. ${ }^{13}$

To avoid confusion as to the true objective of this article, it must be emphasised that the proposal here is not for large-scale divestitures in all cases where dominance and market concentration are found to exist. The article considers and advocates the use of divestiture in two limited circumstances already recognised and provided for under the law - that is, in cases of repeat or serious abuse of dominance that cannot adequately be remedied by other remedies provided for in the Act, ${ }^{14}$ and at the conclusion of a market inquiry, where the Competition Commission is of the opinion that the concentrated nature of the market is likely to have an adverse effect on competition. ${ }^{15}$ This means that less serious and some first-time abuse-ofdominance cases are excluded from the scope of this article. Also excluded are instances of market concentration where there has been no market inquiry conducted, or where a market inquiry conducted has not determined that divestiture is a suitable remedy.

Following the introduction provided in section one above, the ensuing discussion is structured as follows: section two provides the background to the main issues and problem dealt with in the article; section three highlights the problem of concentration in the South African economy; section four outlines the legislative framework for divestiture in non-merger cases in South African competition law; section five considers the feasibility and

99 of 1998.

10 O'Connor 1976 Harvard Journal on Legislation 689-690; Oppenheim "Economic Background" 195019 George Washington Law Review 120 126; Tajana "If I Had a Hammer: Structural Remedies and Abuse of Dominant Position" 20067 Competition and Regulation in Network Industries 36.

11 S 60(1) and (2) of the Competition Act.

12 See Competition Amendment Act 18 of 2018 (2018 Amendment Act).

$13 \mathrm{~S} 43 \mathrm{C}(1)$ and (2) of the Competition Act as introduced by s 26 of the 2018 Amendment Act.

$14 \mathrm{~S} 60(2)$ of the Competition Act.

15 S 43D(2) of the Competition Act as introduced by s 26 of the 2018 Amendment Act, read together with s 60(2) of the Competition Act as amended by s 34 of the 2018 Amendment Act. 
constitutionality of the remedy of divestiture; section six considers some notable cases, in South Africa and abroad, in which divestiture was preferred or considered as a suitable remedy in non-merger cases; and section seven provides a summary of the main observations and conclusions of the article.

\section{BACKGROUND}

After celebrating the twentieth anniversary of the coming into force of the South African Competition Act it may be an opportune time to assess the effectiveness of the Act in achieving its goals. Among the ills the Act was intended to cure were high levels of industrial concentration in the economy and the racially skewed patterns of ownership of the productive assets in the economy. ${ }^{16}$ However, various reports have suggested that the Competition Act has not been very successful in this regard. ${ }^{17}$ While the Act provides some remedies, including divestiture, that may be useful in addressing the problem of concentration, divestiture as a remedy has been underused. A major part of the reasons for the underuse of the remedy of divestiture in our law is that divestiture is treated as a remedy of last resort, especially in nonmerger cases.

While divestiture may be acceptable in merger cases, the prevailing practice in competition-law enforcement is to eschew the remedy in nonmerger cases. The underuse of the divestiture remedy in non-merger cases is directly linked to how the remedy is seen in society. Divestiture is considered the most drastic and aggressive competition-law remedy. ${ }^{18}$ Structural remedies, of which divestiture is a major one, are seen as having the effect of modifying the allocation of property rights. ${ }^{19}$ As former American Senator, Howell T Helflin, also observed in a Senate hearing on proposed amendments to the Federal Trade Commission Act, ${ }^{20}$ "divestiture raises the question whether private property can be taken away by a government agency action." 21

See Preamble to the Competition Act.

17 Citing various World Bank studies, Buthelezi, Mtani and Mncube observe that the South African economy remains highly concentrated, even with years of the application of the Competition Act (Buthelezi, Mtani and Mncube https://www.ellipsis.co.za/wpcontent/uploads/2018/09/The-extent-of-market-concentration-in-South-Africa's-productmarkets-CC-Working-Paper.pdf 4-7).

18 Kovacic "Designing Antitrust Remedies for Dominant Firm Misconduct" 199931 Connecticut Law Review 12851294.

19 Tajana 2006 Competition and Regulation in Network Industries 6. Binge and Van Eeden Remedy Design and Application in South Africa Paper presented at the Fourth Annual Competition Commission, Competition Tribunal and Mandela Institute Conference on Competition Law, Economics and Policy in South Africa, University of the Witwatersrand, Johannesburg, (August 2010) 5.

201914.

21 Federal Trade Commission-Divestiture Hearing Before the Subcommittee for Consumers of the Committee on Consumers, Science, and Transportation United States Senate NinetySixth Congress (30 November 1979) SN 96-671. 
By virtue of the significance of the Constitution in the application of law in South Africa, ${ }^{22}$ the author in due course considers the question of the constitutionality of divestiture as a remedy. ${ }^{23}$ It is, however, appropriate to point out that while the question of the constitutionality of divestiture is significant, it is a question that nonetheless lies beyond the main scope of this article. As a result, consideration of the constitutionality question will be relatively brief. The article, in large part, proceeds from the point of view that, because the kind of divestiture advocated for here is that which is already provided for under the Competition Act, such divestiture is clearly legal and possibly, from the perspective of the principle of legality, also constitutional.

Another difficulty faced by the remedy of divestiture is that it is also seen as a departure from the well-established idea that state interference in the economy should be limited, as free markets are seen as capable of selfcorrecting. ${ }^{24}$ The argument against divestiture may also be more persuasive from an investment perspective. Investors are not likely to want to invest their capital in a country whose government, through their competition agencies, will freely interfere with investments through divestiture. As a result, competition authorities may refrain from decreeing aggressive competition-law remedies, such as divestiture, even when such measures may be necessary. They may feel that they are constrained (politically, economically and socially) from imposing remedies that may be seen as market-unfriendly and may potentially also lead to job losses.

The above background about difficulties that may be encountered in the use of the divestiture remedy may provide some perspective from which the continued concentration of many markets in the South African economy may be understood. ${ }^{25}$ To the extent that the structure of the South African economy has remained largely concentrated, abusive and anticompetitive conduct have remained a permanent feature of many markets in the economy. ${ }^{26}$ Indeed, the South African Competition Commission is inundated with complaints of abusive and anticompetitive conduct on a daily basis. ${ }^{27}$ In line with the Structure-Conduct-Performance Paradigm, anticompetitive conduct is often a product of markets in which it occurs: the more concentrated the market, the more likely it is that abuse of dominance and collusion will occur. ${ }^{28}$ In such a scenario, traditional antitrust remedies (such as an administrative penalty or fine) may be less effective. Undeterred firms

22 Under s 2 of the Constitution of the Republic of South Africa, 1996 (the Constitution), the Constitution is the supreme law of the land, and any law or conduct inconsistent with it is invalid and unconstitutional.

23 See section 5 of the article.

24 However, the policy preference away from government controls toward free-market principles, it has been argued, is also not without its own problems; see Intoccia "Governing Telecommunications: A New Regime in Public Law and Public Policy" 199110 Glendale Law Review 12.

25 Buthelezi, Mtani and Mncube https://www.ellipsis.co.za/wp-content/uploads/2018/09/Theextent-of-market-concentration-in-South-Africa's-product-markets-CC-Working-Paper.pdf 4-7.

26 See Competition Commission of South Africa http://www.compcom.co.za/wpcontent/uploads/2019/10/Annual-Report-2018-2019.pdf 24-32.

27 Ibid.

28 Buthelezi, Mtani and Mncube https://www.ellipsis.co.za/wp-content/uploads/2018/09/Theextent-of-market-concentration-in-South-Africa's-product-markets-CC-Working-Paper.pdf 3. 
may simply embrace the fine as just another cost of trading, which unfortunately may eventually be passed on to the consumer. ${ }^{29}$

Divestiture may, in appropriate circumstances, be the most suitable and effective remedy. The remedy of divestiture, when applied to disrupt the stranglehold of one or a few firms in the market and to encourage entry and broader participation and competition in the market, may be more desirable. As Adams observed, from a competition-law point of view, the hard core of the monopoly problem is the concentration of economic power - particularly the ownership and control of a large proportion of the economy - in the hands of a small number of corporations and individuals. ${ }^{30}$ In his view, this problem can only be solved in one way: dissolution. ${ }^{31}$ With inequality constituting a major problem in many societies, it is becoming clear that the sustainability of many democracies will in part depend on promoting inclusivity in the economy. ${ }^{32}$

The Competition Commission of South Africa has redesigned its 2030 Vision and its mission statements to make bold references to its commitment to regulate competition to achieve "a growing and inclusive economy". ${ }^{33}$ This means that a tailor-made application and enforcement approach for the Competition Act, suited to our own circumstances, will be required. The National Development Plan acknowledges as much, stating that "to pave the way for accelerated economic growth ..., South Africa needs to make tough decisions", including the encouragement of "vigorous competition in markets through the application of competition laws." 34

Chicago-School-inspired competition-law enforcement theory, which holds generally that the goal and focus of competition law should be limited to efficiency and consumer welfare, ${ }^{35}$ cannot work effectively in a society like South Africa, where the majority of citizens are poor and excluded from any meaningful participation in the economy. Indeed, the Chicago-Schoolinspired efficiency-driven competition-law enforcement model is likely to further impoverish communities and deepen inequality, ${ }^{36}$ especially if applied without regard to our circumstances.

Although investment considerations may favour a reluctance to use drastic competition-law remedies, such as divestiture, there is sufficient legal authority and history, in South Africa and abroad, to support effective use of divestiture as a competition-law remedy. The economic and social arguments in favour of divestiture are also profound: any society that

29 Munyai A Critical Review of the Treatment of Dominant Firms in Competition Law: A Comparative Study (doctoral thesis, University of South Africa) 2016 120-121.

30 Adams "Dissolution, Divorcement, Divestiture: The Pyrrhic Victories of Antitrust" 195127 Indiana Law Journal 11.

31 lbid.

32 Bogus "The New Road to Serfdom: The Curse of Bigness and the Failure of Antitrust" 2015 49 University of Michigan Journal of Law Reform 12.

33 Competition Commission of South Africa "About Us" http://www.compcom.co.za/about-us-2/ (accessed 2020-04-08).

34 South African Government, National Development Plan 2030 (15 August 2012) 114-115.

35 Kelly, Unterhalter, Youens, Goodman and Smith Principles of Competition Law in South Africa (2017) 6.

36 Bogus 2015 University of Michigan Journal of Law Reform 1. 
excludes the majority of its population from any meaningful participation in the economy is bound to fail. ${ }^{37}$ For this reason, the Competition Act expressly makes provision for the remedy of divestiture, ${ }^{38}$ which could be relevant in circumstances where anticompetitive conduct is made possible by the concentrated and oligopolistic structure of the market.

It may be encouraging to note that advanced economies and mature competition-law jurisdictions, such as the United States, have effectively also used the divestiture remedy when economic circumstances required. ${ }^{39}$ For a society founded on democracy, capitalism and the free-market idea, the effective use of the divestiture remedy at a time when the American economy was highly concentrated makes America an interesting case study for South Africa. The South African economy has a long history of monopolies and industrial concentration, ${ }^{40}$ which has also been organised along racial lines. In the discussion that follows, the author considers the problem of economic concentration in the South African economy.

\section{THE PROBLEM OF CONCENTRATION IN THE SOUTH AFRICAN ECONOMY}

It is not the aim of this part to provide a grand-scale review of the structure of the South African economy. Such an exercise may be suitable for an article on industrial organisation. ${ }^{41}$ For purposes of this article, it suffices to show that there is evidence to support the view that the South African economy is highly concentrated. The demonstration of evidence of concentration in the South African economy is appropriate to establish a competition-law perspective from which the remedy of divestiture may appear relevant.

The fact that concentration and monopolies have long been characteristic features of the structure of the South African economy is so central to the understanding of the South African economic structure that it is now taken for granted. In 1949, addressing Parliament, the then-Minister of Economic Affairs observed, "there was an undoubted tendency towards the creation of

37 In the background note accompanying the 2018 Amendment Act, the Minister of Economic Development, Mr Ibrahim Patel, stated: "[i]t is important to note the economic argument for transformation. Concentrated markets that inhibit new entrants and that, accordingly, exclude large numbers of black South Africans from the opportunity to run successful enterprises, are not a basis for strong and sustained growth. They continue to limit the talent pool of entrepreneurs on which the growth potential of the economy relies. An inclusive growth path requires that we address these barriers to entry - whether they are regulated or presently hidden from scrutiny." See Competition Amendment Bill 2017, GN 1345 in GG 41294 of 2017-12-01 7.

38 S 58(1)(a)(iv) and 60 of the Competition Act, as amended by ss 32 and 34 of the 2018 Amendment Act.

39 Letwin Law and Economic Policy in America (1967) 15, 54 and 59; Thorelli The Federal Antitrust Policy: Origination of an American Tradition (1954) 1-5.

40 Cowen "A Survey of the Law Relating to the Control of Monopoly in South Africa" 19508 South African Journal of Economics 124 124; Bekker Monopolies: Review of the Role of the Competition Board (1992) 13; Bekker "Monopolies and the Role of the Competition Board" 1992 Journal of South African Law 618625.

41 This is the study of markets and their structure; see Carlton and Perloff Modern Industrial Organization (2015) 26. 
monopolies in South Africa". ${ }^{42}$ At the end of apartheid, many sectors of the economy were characterised by their monopolies and high levels of concentration. ${ }^{43}$ The incoming ANC government also inherited an economy with many state-owned monopolies, conglomerates and high market concentration levels. ${ }^{44}$ As Roberts observed, "not more than five conglomerate groupings controlled the majority of economic activity in the country". ${ }^{45}$ There is also little doubt that, to this day, many key markets in the South African economy remain highly concentrated. ${ }^{46}$

While there are different methods that can be used to measure concentration, the most commonly accepted method for measuring market concentration is the Herfindahl-Hirschman Index $(\mathrm{HHI}) .{ }^{47}$ This model measures concentration levels in markets by allocating scores to the aggregate market shares of all market participants, ranging from zero (representing a state of perfect competition in the market where concentration is replaced by several firms of equal size competing in the market) to 10000 (representing a state of imperfect competition in the market where competition is replaced by monopoly). ${ }^{48}$ In the United States of America, antitrust agencies consider markets in which the $\mathrm{HHI}$ is between 1500 and 2500 to be moderately concentrated and markets in which the $\mathrm{HHI}$ is in excess of 2500 to be highly concentrated. ${ }^{49}$ In the United Kingdom, a market with an $\mathrm{HHI}$ exceeding 1000 may be deemed to be concentrated whereas a market with an $\mathrm{HHI}$ exceeding 2000 may be regarded as highly concentrated. ${ }^{50}$

In a study spanning 2150 merger decisions between January 2009 and March 2016, the South African Competition Commission's investigation has

42 Cowen 1950 South African Journal of Economics 124; Bekker Monopolies: Review of the Role of the Competition Board 13; Bekker 1992 Journal of South African Law 625.

43 Tregenna-Piggott An Assessment of Competition Policy in South Africa Occasional Paper No. 8 Economic Research Unit Department of Economics, University of Natal (1980) 6; Roberts "The Role for Competition Policy in Economic Development: The South African Experience" (March 2004) https://www.researchgate.net/publication/227610905_The Role_for_Competition_Policy_in_Economic_Development_The_South_African_Experience $1-2$.

44 Smit The Rationale for Competition Policy: A South African Perspective Paper presented at the Biennial ESSA Conference, Durban (2005) 1.

45 Roberts https://www.researchgate.net/publication/227610905_The_Role_for_Competition Policy_in_Economic_Development_The_South_African_Experience 1-2.

46 Background Note accompanying the Competition Amendment Bill, 2017, GN 1345 in GG 41294 of $2017-12-0110$.

47 The United States Department of Justice "Herfindahl-Hirschman Index" https://www.justice.gov/atr/herfindahl-hirschman-index (accessed 2020-04-08); Buthelezi, Mtani and Mncube https://www.ellipsis.co.za/wp-content/uploads/2018/09/The-extent-ofmarket-concentration-in-South-Africa's-product-markets-CC-Working-Paper.pdf 4.

48 The United States Department of Justice, https://www.justice.gov/atr/herfindahl-hirschmanindex; Buthelezi, Mtani and Mncube https://www.ellipsis.co.za/wpcontent/uploads/2018/09/The-extent-of-market-concentration-in-South-Africa's-productmarkets-CC-Working-Paper.pdf 4.

49 See US Department of Justice and Federal Trade Commission Horizontal Merger Guidelines (2010) 19.

50 The United States Department of Justice, https://www.justice.gov/atr/herfindahl-hirschmanindex; Buthelezi, Mtani and Mncube https://www.ellipsis.co.za/wpcontent/uploads/2018/09/The-extent-of-market-concentration-in-South-Africa's-productmarkets-CC-Working-Paper.pdf 5. 
revealed the following: 70,45 per cent of South African sectors have dominant firms in defined product markets; 51 the average $\mathrm{HHI}$ across defined product markets is approximately $2986 ; 5^{52}$ and some priority sectors, ${ }^{53}$ such as the information communication technologies sector, have an $\mathrm{HHI}$ as high as $3539 .{ }^{54}$ Although these figures were based only on the 2150 merger decisions in the affected sectors, rather than the entire economy, the concentration picture painted by the Competition Commission's study is worrying.

A number of recent market inquiries conducted by the Competition Commission into specific sectors of the South African economy have also revealed worrying levels of concentration in those sectors. For example, the Competition Commission's Market Inquiry Into the Liquefied Petroleum Gas Sector has found the market to be highly concentrated and dominated by five firms. ${ }^{55}$ The Competition Commission's market inquiry into the South African private healthcare sector has also identified concentration as among the major problems affecting competition in the market. In particular, the inquiry has revealed that 70 per cent of the open medical schemes market is controlled by two players; ${ }^{56}$ the market for restricted medical aid schemes is dominated by one player; 57 the medical scheme administrators market is controlled by three players; 58 and the market for private hospital facilities is dominated by three hospital groups. ${ }^{59}$

Furthermore, in its recent Grocery Retail Market Inquiry Final Report, the Competition Commission has found that the South African formal grocery retail sector is also highly concentrated. 60 The Commission's report notes specifically that the concentration ratio for the top five largest retailers of grocery products in South Africa (these being Shoprite, Pick n Pay, SPAR, Woolworths and Massmart) is approximately 64 per cent.61 And the Competition Commission's Data Services Market Inquiry has further

51 Buthelezi, Mtani and Mncube https://www.ellipsis.co.za/wp-content/uploads/2018/09/Theextent-of-market-concentration-in-South-Africa's-product-markets-CC-Working-Paper.pdf 5 and 7.

52 Buthelezi, Mtani and Mncube https://www.ellipsis.co.za/wp-content/uploads/2018/09/Theextent-of-market-concentration-in-South-Africa's-product-markets-CC-Working-Paper.pdf 7.

53 The Competition Commission has identified some sectors it considers priority sectors namely, food and agro-processing; infrastructure and construction; intermediate industrial products; financial services; energy; and information communication technologies sectors.

54 Buthelezi, Mtani and Mncube https://www.ellipsis.co.za/wp-content/uploads/2018/09/Theextent-of-market-concentration-in-South-Africa's-product-markets-CC-Working-Paper.pdf 7.

55 Competition Commission of South Africa Market Inquiry Into the LPG Sector: Final Report (2017) par 17. See also par 5.17, 6.10-6.12 and 18.

56 Competition Commission of South Africa Health Market Inquiry (2019) 105 par 12.

57 Competition Commission of South African Health Market Inquiry 105 par 13.

58 Competition Commission of South African Health Market Inquiry 106 par 16 and 125 par 155.

59 Competition Commission of South African Health Market Inquiry 101 par 229.1.

60 Competition Commission of South Africa Grocery Retail Market Inquiry Final Report (2019) 63-65.

61 Ibid. 
revealed that the market is also highly concentrated and specifically dominated by two players. ${ }^{62}$

It should be of concern that the trend towards industrial concentration in the South African economy has not shown signs of decreasing, despite the Competition Act having been in operation for over 20 years. This concern is informed by the fact that the development of competition policy in South Africa was directly connected to the State's efforts to address the problems of monopoly and the excessive concentration of economic power in the hands of a few individuals and firms. ${ }^{63}$ The role of the Competition Act in South African society must, to a large extent, be seen in this context. The Act makes explicit reference to the problem of concentration, ${ }^{64}$ and enjoins competition authorities to find ways, within the framework of the Act, to address this problem. Among the many mechanisms provided for in the Act to address the problem of concentration and the abuse of market power is the remedy of divestiture. 65

\section{DIVESTITURE IN NON-MERGER CASES UNDER THE COMPETITION ACT}

Among the lesser-known provisions of the Competition Act, even among those with a fair understanding of competition law, are those relating to the remedy of divestiture, particularly as applied to non-merger cases. The Competition Act makes explicit provision for the remedy of divestiture, even in non-merger cases. Section 58 of the Competition Act empowers the Competition Tribunal to make an order of divestiture in relation to a prohibited practice. ${ }^{66}$ The Act defines a prohibited practice as a practice prohibited under Chapter Two of the Act. Chapter Two of the Act prohibits various forms of anticompetitive practices, including the abuse of a dominant position. ${ }^{67}$ Section 58 further provides that, when making an order of divestiture, the Competition Tribunal must have regard to the provisions of section 60 of the Act. Section 60 provides, in relevant parts, that the Competition Tribunal may impose the remedy of divestiture in cases involving the abuse of dominance, provided that the abusive conduct (i) cannot adequately be remedied under any other provision of the Act: ${ }^{68}$ or

62 Competition Commission of South Africa Data Services Market Inquiry Final Report (2019) 21 par 20, 41 par 76, 81 par 199, 85 par 205.1, 86 par 206, 87 par 210, 92 par 216, 94 par 217 and 219.

63 Roberts https://www.tips.org.za/research-archive/trade-and-industry/centre-for-realeconomy-study-crest/item/385-the-role-for-competition-policy-in-economic-developmentthe-south-african-experience 7; Australian Competition and Consumer Commission Better Regulation of Economic Infrastructure: Country-Based Review Working Paper No. 8 (2013) 10.

64 The explicit reference to the structural and transformative objectives in the Competition Act, it is submitted, "clearly indicates that the legislature intended that competition policy should be broadly framed, embracing both traditional competition issues, as well as these explicit transformative public interest goals"; see Competition Amendment Bill 2017, GN 1345 in GG 41294 of 2017-12-016.

$65 \mathrm{~S} 60$ of the Competition Act.

66 S 58(1)(iv) of the Competition Act.

$67 \mathrm{~S} 8$ of the Competition Act.

68 S 60(2)(b)(i) of the Competition Act. 
(ii) is substantially a repeat by the same firm of conduct previously found by the Tribunal to be prohibited. ${ }^{69}$ The Act further provides that an order of divestiture by the Tribunal is of no force or effect unless confirmed by the Competition Appeal Court. ${ }^{70}$

The provisions of section 60 of the Competition Act, particularly those that limit the application of the remedy of divestiture to cases of serious abuse of dominance that cannot adequately be remedied through other remedies under the Act, and repeat abusive conduct, indicate the legislature's view that divestiture must be used sparingly and as a remedy of last resort. ${ }^{71}$ This may explain why the remedy of divestiture is almost unknown in South African competition law. It is no surprise then that, after more than 20 years of the application of the Competition Act, the structure of the South African economy remains largely concentrated. However, the recent Competition Amendment Act ${ }^{72}$ appears to take the remedy of divestiture quite seriously when regard is had to the problem of concentration in the economy.

The Competition Amendment Act, which came into force on 12 July 2019,73 was passed against a backdrop of political concerns that the Competition Act did not sufficiently empower competition authorities to take measures to address the problem of concentration in the economy. ${ }^{74}$ As the most radical competition statute to date, the Amendment Act seeks, among other things, to reinforce existing provisions of the Competition Act relating to prohibited practices (particularly abuse of dominance) and to strengthen market inquiries. ${ }^{75}$ Fundamental to the Amendment Act is the desire "to address two persistent structural constraints on the South African economy, namely, the high levels of economic concentration in the economy and the skewed ownership profile in the economy". ${ }^{76}$

Under the Amendment Act, market inquiries will probably become the chief instrument to address the problems of economic concentration and skewed ownership in the economy. Following the Amendment Act, the focus of market inquiries will no longer just be on the general state of competition in a market, but also on the levels of concentration and the structure of the market. ${ }^{77}$ In a market inquiry, the Competition Commission is required to determine whether any feature of the market, including the structure and levels of concentration, may have an adverse effect on competition. ${ }^{78}$

\footnotetext{
$\mathrm{S} 60(2)(b)$ (i) of the Competition Act.

S 60(3) of the Competition Act.

71 Cise "Limitations Upon Divestiture" 195019 George Washington Law Review 147 148. The classic and basic argument for divestiture is that the defendant or defendants have assumed such complete domination of the market that free competitive conditions cannot be restored by injunctive relief alone. See Timberg "Some Justifications for Divestiture" 195019 George Washington Law Review 132133.

72 Competition Amendment Act 18 of 2018.

73 Presidential Proclamation No. 46 of 2019 in GG 42578 of 2019-07-12.

74 Background Note accompanying the Competition Amendment Bill GN 1345 in GG 41294 of 2017-12-01 9 and 11

75 See Memorandum on the Objects of the Act in its Bill stage, Competition Amendment Bill B 23B-2018 par 2.2.

76 Competition Amendment Bill B 23B-2018 par 2.2

$77 \mathrm{~S} 43 \mathrm{~A}(1)$ of the Competition Act as amended by s 23 of the 2018 Amendment Act.

78 S 43C(1) and (2) of the Competition Act, as introduced by s 26 of the 2018 Amendment Act.
} 
If the Competition Commission finds any feature of the market to have an adverse effect on competition, the Amendment Act obliges the Commission to determine steps to be taken to remedy that adverse effect. Such steps may include the Commission itself taking steps to remedy, mitigate or prevent the adverse effect on competition or could consist of making a recommendation to the Competition Tribunal for an appropriate order. ${ }^{79}$ One of the orders that the Competition Tribunal may make to remedy an adverse effect on competition following a recommendation of the Competition Commission is an order of divestiture ${ }^{80}$ Should the Tribunal make an order of divestiture, such an order will require confirmation by the Competition Appeal Court. ${ }^{81}$

The Amendment Act clearly makes good on a promise (made in the statement of purpose in the preliminary Bill introducing the Amendment Act) to address the problems of high levels of concentration and skewed ownership in the economy. ${ }^{82}$ Whenever a market inquiry reveals that any feature of a market, including the structure and levels of concentration in the market, has an adverse effect on competition, the Amendment Act places a duty on competition authorities to take appropriate remedial steps. ${ }^{83}$ If there were ever any doubt as to whether South African competition authorities are required or even empowered to intervene in the economy to address the problem of concentration through bold measures such as divestiture, now such doubts must be considered extinguished. Whereas divestiture in nonmerger cases was initially only allowed in very limited cases under the Competition Act, ${ }^{84}$ now divestiture can also be used to address the problem of concentration if a market inquiry finds such concentration to have an adverse effect on competition. However, despite the now more explicit and bold provisions of the law providing for divestiture in concentrated markets, the important question is whether there will be enough will on the part of competition authorities to implement this remedy. An equally important and relevant question is whether divestiture, especially as provided for under the Amendment Act, can survive constitutional scrutiny.

\section{5 FEASIBILITY AND CONSTITUTIONALITY OF
DIVESTITURE}

Divestiture is not new or alien to competition law. ${ }^{85}$ It is in fact a widely accepted remedy in competition law, particularly in merger cases. At least

79 S 43D(1) and (2) of the Competition Act, as introduced by s 26 of the 2018 Amendment Act.

$80 \mathrm{~S} 43 \mathrm{D}(2)$ of the Competition Act, as introduced by s 26 of the 2018 Amendment Act, read together with s 60(2) of the Competition Act as amended by s 34 of the 2018 Amendment Act.

81 S 60(3) of the Competition Act, as amended by s 34 of the 2018 Amendment Act.

82 Background Note accompanying the Competition Amendment Bill GN 1345 in GG 41294 of 2017-12-01 6-12.

83 S 43D(1)-(3) of the Competition Act as introduced by s 26 of the 2018 Amendment Act.

84 These would be cases involving the abuse of a dominant position under section 8 of the Act and where the abuse cannot adequately be remedied by any other provision of the Act or where such abuse is essentially a repeat by the same firm of conduct previously found to constitute an abuse of dominance.

85 Anonymous "Aspects of Divestiture as an Antitrust Remedy" 196332 Fordham Law Review 135136. 
from a merger perspective, this means that there is already considerable precedent and expertise in the use of the divestiture remedy in competition law. Thus, in formulating and enforcing the remedy in non-merger cases, competition authorities will be able to draw on the experience and expertise they already have in administering the divestiture remedy - in merger cases, for the most part.

In merger cases, competition authorities across the world, it is submitted, prefer imposing structural remedies (of which divestiture is a major example) over behavioural remedies. ${ }^{86}$ Even some of the most respected competition authorities around the world, including in the United States, the European Commission and United Kingdom, have expressed their preference for the use of structural remedies in merger cases. ${ }^{87}$ Other European nations like Netherlands and Germany are also among countries that favour structural remedies in merger cases. ${ }^{88}$ South African competition authorities have also expressed their preference for structural remedies in merger cases, although in practice they have mostly imposed more behavioural remedies. ${ }^{89}$ However, South African competition authorities have also not shied away from imposing structural remedies and divestiture when circumstances required. ${ }^{90}$

As far as mergers are concerned, the European Commission has explicitly made clear its preference for structural remedies. In a 2008 notice, the European Commission announced that structural remedies, and divestiture in particular, "are, as a rule, preferable from the point of view of merger control, as they prevent, durably, the competition concerns which would be raised by a merger." ${ }^{11}$ A 2005 study by the European Director-General for Competition had earlier also shown that 84 per cent of merger remedies imposed by the European Commission between 1996 and 2000 were structural. ${ }^{92}$ In its merger remedy guide issued in 2004, the United States Department of Justice also indicated that "structural remedies are preferred

86 Binge and Van Eeden paper presented at the Fourth Annual Conference on Competition Law, Economics and Policy in South Africa 27.

87 Ngwenya and Robb "Theory and Practice in the Use of Merger Remedies: Considering South African Experience" 20114 Journal of Economic and Financial Sciences 203204.

88 Ngwenya and Robb 2011 Journal of Economic and Financial Sciences 209. See also Hoehn "Structure Versus Conduct: A Comparison of the National Merger Remedies Practice in Seven European Countries" 2010 International Journal of the Economics of Business 9-32.

89 Mariotti "South African Merger Remedies: What Have We Learnt in the Last Ten Years" 20106 Competition Law International 5555 and 57.

90 Astral Foods/National Chick Case No. 69/AM/Dec01; Distillers/Stellenbosch Farmers Winery Case No. 31/CAC/Sep03; Roofing/Kula Enterprises Case No. 63/LM/Jul06; ATC Telecoms/Aberdare Case No. 70/LM/Aug06; Oceana Group Limited/Foodcorp (Pty) Ltd Case No: 018101.

91 European Commission Commission Notice on Remedies Acceptable Under Council Regulation (EC) No 139/2004 and Under Commission Regulation (EC) No 802/2004 (2008/C 267/01) 4 par 15.

92 European Commission, DG Competition Merger Remedies Study (October 2005); Ngwenya and Robb 2011 Journal of Economic and Financial Sciences 209. 
to conduct remedies in merger cases, because they are relatively clean and certain." 93

However, in abuse of dominance and monopolisation cases, structural remedies, and divestiture in particular, are not popular. Most agencies, it has been observed, prefer behavioural remedies because they are viewed as more light-handed. ${ }^{94}$ In South Africa, competition authorities also seem to prefer behavioural remedies over structural remedies in cases involving prohibited practices. ${ }^{95}$ This is because there are some risks associated with the remedy and process of divestiture. The International Competition Network has classified these risks as follows: composition risk (which refers to the scope of the remedy); purchaser risk (which relates to the risk related to the purchase - in particular, finding a suitable purchaser for the affected asset); and asset risk (the risk of the asset depreciating in value). ${ }^{96}$ In sum, the article notes that there are indeed many criticisms and concerns that have been directed at structural remedies in general and divestiture in particular.

However, this does not of course mean that non-structural remedies, in particular behavioural remedies, are perfect. Behavioural remedies have their weaknesses too. One of the major criticisms levelled against behavioural remedies is that they do not deal effectively or directly with the problem of concentration and market power. ${ }^{97}$ By contrast, structural remedies (particularly divestiture) have the advantage that they can directly address the problem of concentration and encourage competition. ${ }^{98}$

There may be cases where dominant firms in concentrated markets are emboldened by their market power to engage in anticompetitive conduct. ${ }^{99}$ As far as abusive conduct is concerned, it is sometimes not enough for a competition authority merely to put an end to the conduct. In some cases, there may also be a need to ensure that measures are in place to prevent a future repeat of the same conduct by the same or even other firms. A remedy designed only to put an end to the anticompetitive conduct may miss the important fact that the defendant, through such anticompetitive conduct, may have already gained and protected a position of dominance from which it may continue to benefit if nothing more is done. ${ }^{100}$ In such cases, divestiture may be a suitable remedy.

93 US Department of Justice (Antitrust Division) Antitrust Division Policy Guide to Merger Remedies (October 2004) 7 par A.

94 OECD Remedies and Sanctions in Abuse of Dominance Cases (2006) 9; Binge and Van Eeden paper presented at the Fourth Annual Conference on Competition Law, Economics and Policy in South Africa 5.

95 Binge and Van Eeden paper presented at the Fourth Annual Conference on Competition Law, Economics and Policy in South Africa 7.

96 International Competition Network Merger Remedies Review Project. Report for the Fourth ICN Annual Conference, ICN Merger Working Group: Analytical Framework (2005) 8 par 3.9.

97 OECD Remedies and Sanctions in Abuse of Dominance Cases 8.

98 Ibid.

99 OECD Remedies and Sanctions in Abuse of Dominance Cases 9.

100 Standard Oil Co of New Jersey v United States 221 US 1 (1911) 77; Binge and Van Eeden paper presented at the Fourth Annual Conference on Competition Law, Economics and Policy in South Africa 2. 
However, by its nature, divestiture may raise some constitutional questions, especially from the perspective of property rights. A study of some foreign case law, in which the legality and constitutionality of divestiture was challenged, shows that divestiture may survive these challenges.

In United States $v$ American Tobacco Co, ${ }^{101}$ one of the early and notable monopolisation cases under section 2 of the Sherman Act, the Supreme Court of the United States, per Chief Justice White, stated that when imposing a remedy such as divestiture, a court must, among a list of factors to be considered, also give due consideration to any possible hardship that may result to private property interests. ${ }^{102}$ However, the court was of the view that any possible hardships that could result to private property interests in this case were outweighed by the public interest promoted by maintaining healthy competition in the market; it thus concluded that divestiture was the most appropriate and effective remedy. ${ }^{103}$ Years later, in United States v E.I. du Pont de Nemours \& Co, ${ }^{104}$ the US Supreme Court, per Justice Brennan, remarked that where alternative remedies will not be effective in providing redress to the dangers posed to the economy by monopoly, the occasion to consider private property interests, prior to a decree of divestiture, may not even arise. ${ }^{105}$

In $D u$ Pont, ${ }^{106}$ the Supreme Court also emphasised that divestiture is an equitable remedy designed to protect the public interest. ${ }^{107}$ The court further remarked that, if a court is of the view that other measures will not effectively address an antitrust violation, and that complete divestiture is a necessary element of effective relief, the Government will not be denied the remedy of divestiture simply because economic hardship, however severe, may result. ${ }^{108}$ The possibility that divestiture will have harsh consequences for those against whom it is directed, the court further found, will hardly be of material assistance to those who seek to rely on this argument as a basis to challenge divesture. ${ }^{109}$ Confident in its decision, that divestiture was the most appropriate remedy in this case, the Supreme Court noted that decrees mandating divestitures have never meaningfully been challenged, as divestiture was deeply rooted in American antitrust law. ${ }^{110}$

As the modern American economy became deconcentrated, divestiture orders have become rare. However, some modern cases, like United States $v$ Microsoft Corp, ${ }^{111}$ have decreed divestiture. Although the District Court's decision in Microsoft was later overturned on appeal, ${ }^{112}$ it is important to note

\footnotetext{
221 U.S. 106 (1911).

United States v American Tobacco Co supra 185.

United States v American Tobacco Co supra 187.

366 U.S. 316 (1961).

United States v E.I. du Pont de Nemours \& Co supra 328.

66 Supra.

United States v E.I. du Pont de Nemours \& Co supra 326.

8 United States v E.I. du Pont de Nemours \& Co supra 327.

United States v E.I. du Pont de Nemours \& Co supra 326.

10 United States v E.I. du Pont de Nemours \& Co supra 327.

1187 F. Supp. 2d 30 (D.D.C. 2000).

112 United States v Microsoft Corp 253 F. 3d 34 (D.C. Cir. 2001).
} 
that the Court of Appeals overturned the decision for other reasons ${ }^{113}$ and not on the unconstitutionality of divestiture itself. Some American commentators hold the view that divestitures still have a place in modern American antitrust law. In a recent article, Bogus (inspired by Brandeis's Curse of Bigness) ${ }^{114}$ calls for a radical change in American antitrust policy to tackle "behemoth corporations, consolidated industries, and enormous wealth flowing into the hands of a few". ${ }^{115} \mathrm{He}$ also argues that antitrust law should be used to break up large financial institutions, the failure of which may result in significant economic hardships, as witnessed during the 2008 global financial crisis. ${ }^{116}$

Down under, particularly in Australia, there are no doubts as to the constitutional validity of divestiture provisions. ${ }^{117} \mathrm{~A}$ few cases have declared that divestiture is valid and constitutional, notably Trade Practices Commission v The Gillette Company (No 2) ${ }^{118}$ and Wsgal Pty Limited v Trade Practices Commission, the Gillette Company, Wilkinson Sword Limited and Registrar of Trade Marks. ${ }^{119}$ In Wsgal Pty Limited, upholding the constitutional validity of the divestiture provision (section 81) of the Australian Trade Practices Act of 1974, ${ }^{120}$ the Full Federal Court found that the provision seeks to adjust the competing rights of different parties in an area of activity where Parliament is most concerned about the maintenance of competition in trade and commerce in the public interest. ${ }^{121}$

In South Africa, where the constitutionality of divestiture as a competitionlaw remedy has not yet been considered by our courts, it is reasonable to suggest that the measure, if employed sensibly, ${ }^{122}$ will survive constitutional scrutiny. As foreign case law referred to above guides us, divestiture orders seek to balance the competing commercial and property interests of the divested firm and the public interest in having markets that are competitive. In cases where South African competition authorities are of the view that divestiture would be the most effective remedy through which the public interest in maintaining competition in markets could be protected, it would

113 These included that a number of the District Court's liability determinations were flawed and could not survive appellate review; the District Court failed to hold an evidentiary hearing to address remedies-specific factual disputes; and that the trial judge engaged in impermissible ex parte contacts by holding secret interviews with members of the media and made numerous offensive comments about Microsoft officials in public statements outside of the courtroom, giving rise to an appearance of partiality.

114 McGraw Prophets of Regulation: Charles Francis Adam, Louis D. Brandeis, James M. Landis, Alfred E. Kahn (1986); Brandeis The Curse of Bigness: Miscellaneous Papers of Louis D. Brandeis Fraenkel (ed) (1934).

115 Bogus 2015 University of Michigan Journal of Law Reform 2-3.

116 Bogus 2015 University of Michigan Journal of Law Reform 115.

117 Steinwell "Constitutional Validity of Divestiture Orders" 199417 University of New South Wales Law Journal 651.

1181993118 ALR 280.

1191994 FCA 1079; (1994) 122 ALR 673.

120 Wsgal Pty Limited v Trade Practices Commission supra par 36 and 41.

121 Wsgal Pty Limited v Trade Practices Commission supra par 40.

122 For e.g., in serious or repeat cases of abuse of dominance and where no alternative remedy will be effective in remedying the problem, as well as in cases where a market inquiry determines that no alternative remedy, other than divestiture, will be sufficient to remedy the adverse effect on competition brought about by the high levels of concentration. 
seem that such a decision could be justified under section 36 of the Constitution. ${ }^{123}$

It is therefore not surprising that there have been some non-merger cases where courts and competition authorities have had to consider and administer the remedy of divestiture. These cases are looked at in the discussion that follows.

\section{DIVESTITURE IN NON-MERGER CASES}

Although European competition law empowers the European Commission, in abuse of dominance cases, to adopt structural remedies as a means to bring infringement of the rules of competition to an end, the Commission has rarely used divestiture. ${ }^{124}$ The United States leads the way in this regard. In a 2001 study, Crandall examined remedies imposed in 336 monopolisation cases, of which he found 95 involved structural remedies, and 63 of these involved divestiture. ${ }^{125}$ Although divestiture is traditionally not a popular remedy in abuse of dominance and monopolisation cases, these figures show that structural remedies have indeed been used to a respectable extent in monopolisation cases in the United States. Below, the author considers some notable monopolisation and abuse of dominance cases in the United States and South Africa, in which structural remedies and divestiture were considered.

In Standard Oil of New Jersey v United States ${ }^{126}$ (an historically significant case in American antitrust law), the Supreme Court ordered that Standard Oil, which had monopolised various sectors of the American economy in contravention of section 2 of the Sherman Act, be broken up into over 30 independent corporations. ${ }^{127}$ Standard Oil, it has been observed, set the tone for the next century of monopolisation cases in the United States. ${ }^{128}$ In United States $v$ American Tobacco ${ }^{129}$ (another monopolisation case under section 2 of the Sherman Act), American Tobacco had monopolised the tobacco market to the point where it accounted for over 90 per cent of sales of different tobacco products. It had also grown to include over 100 different companies conducting businesses in the United States and other countries around the world. ${ }^{130}$ The government filed a monopolisation case against the company, seeking to dissolve it entirely. The Supreme Court approved the dissolution of the company but directed a lower court to hear evidence to

123 S 36 provides for the limitation of rights in the Bill of Rights, including the right to property. It would seem that where individual rights to property clash with the public interest to maintain markets that are competitive, the protection of the public interest could carry more weight.

124 See Council Regulation (EC) No. 1/2003 of December 16th 2002 on the implementation of the rules on competition law laid down in Articles 81 and 82 of the Treaty $O J$ L 1, 4.1.2003; Tajana 2006 Competition and Regulation in Network Industries 3-4.

125 Binge and Van Eeden paper presented at the Fourth Annual Conference on Competition Law, Economics and Policy in South Africa 26; Crandall The Failure of Structural Remedies in Sherman Act Monopolization Cases Working Paper 01-05 10 (2001).

126221 US 1 (1911) 77.

127 Standard Oil of New Jersey $v$ United States supra 77-82.

128 Sullivan 2002 Minnesota Law Review 571.

129 Supra.

130 Crandall The Failure of Structural Remedies in Sherman Act Monopolization Cases 27. 
enable it to decide on an appropriate dissolution decree. ${ }^{131}$ The lower court eventually dissolved the company into three cigarette-producing entities. ${ }^{132}$ Standard Oil and American Tobacco are considered two of the most significant early monopolisation cases decided under section 2 of the Sherman Act, ${ }^{133}$ enunciating some of the basic remedial policy underlying a divestiture decree. ${ }^{134}$

In United States v Aluminium Company of America (Alcoa), ${ }^{135}$ Alcoa was charged with restraining trade and monopolising the American aluminium industry. While the district court initially absolved Alcoa of wrongdoing, ${ }^{136}$ the government's appeal to the Court of Appeals was partly successful; Alcoa was found guilty of monopolising a limited part of the market for aluminium. ${ }^{137}$ However, Judge Hand postponed the implementation of divestiture, observing that changes in the aluminium industry, necessitated by America's involvement in World War II, made it impossible for the court to instruct divestiture at the time, as it was not clear what the state of the market would be post-war. ${ }^{138}$

However, it was Judge Hand's remarks about the effects of monopoly in Alcoa that were more telling: "possession of unchallenged economic power deadens initiative and discourages thrift and for that reason the Sherman Act outlawed monopoly in all its manifestations". ${ }^{139}$ Hand observed further that "throughout the history of the Sherman Act, the purpose of the law was to discourage monopoly at all costs and to encourage the existence and preservation of several small independent operators". ${ }^{140}$ As Waller would later observe, the Supreme Court's interpretation of the Sherman Act was rapidly endorsed and set the ground rules for the enforcement of the Sherman Act for a generation. ${ }^{141}$

In United States $v$ AT\& $T, 142$ the government's complaint was that AT\&T had monopolised the telecommunications market in a variety of ways in violation of the Sherman Act. ${ }^{143}$ By means of a consent agreement, the parties reached a settlement agreement, which had to be approved by the court. One of the major issues before the court was the issue of remedy, in particular divestiture, as proposed in the consent agreement between the

\footnotetext{
United States v American Tobacco supra 187.

${ }^{32}$ Crandall The Failure of Structural Remedies in Sherman Act Monopolization Cases 28.

13315 USC ch 1, 1890.

134 Adams 1951 Indiana Law Journal 1.

35148 F.2d 416 (2d Cir. 1945).

136 United States v Aluminium Company of America 44 F. Supp. 97 (S.D.N.Y 1942).

37 United States $v$ Aluminum Co. of America (2d Cir. 1945) 447.

138 United States v Aluminum Co. of America (2d Cir. 1945) 445-446. As Waller also observed, the court deferred the question of remedy until after the end of World War II (Waller "The Past, Present, and Future of Monopolization Remedies" 200976 Antitrust Law Journal 1 16). See also Crandall The Failure of Structural Remedies in Sherman Act Monopolization Cases 40.

139 United States v Aluminum Co. of America (2d Cir. 1945) 427.

140 United States v Aluminum Co. of America (2d Cir. 1945) 429.

141 Waller "The Story of Alcoa: Enduring Questions of Market Power, Conduct, and Remedy in Monopolization Cases" in Fox and Crane (eds) Antitrust Stories (2007) 132.

142552 F. Supp. 131 (D.D.C. 1982).

143 United States v AT\&T supra 160.
} 
government and AT\&T. ${ }^{144}$ The court approved the divestiture, breaking the company into eight separate entities. ${ }^{145}$ In approving the divestiture, the court was particularly concerned about the extent of AT\&T's dominance in the telecommunications market, which the court found to be against the object of antitrust laws. ${ }^{146}$ The court observed that antitrust laws embody "a desire to put an end to great aggregations of capital". 147 Endorsing the remedy of divestiture, the court observed that, following divestiture, AT\&T will no longer have the ability to act to the detriment of its competitors in the relevant markets. ${ }^{148}$

In United States $v$ Microsoft Corp, ${ }^{149}$ a District Court Judge found that Microsoft had established an unlawful monopoly and abused its dominance, and in a separate opinion on remedies, ${ }^{150}$ made an order of divestiture, effectively breaking the corporation into two separate units, one to produce computer operating systems, and the other, software components. ${ }^{151}$ While this decision was later overturned on appeal, ${ }^{152}$ some observers, like Litan and Nordhaus, ${ }^{153}$ still contend that divestiture was an appropriate remedy in that case. They contend that where anticompetitive conduct is made possible mainly by the dominant position of the defendant in the market, divestiture may be a suitable remedy because "it goes to the root cause of the problem". ${ }^{154}$

In South Africa, there have not been many non-merger cases in which the remedy of divestiture was preferred or considered. In Harmony Gold Mining Company Ltd v Mittal Steel South Africa Ltd'155 (an abuse of dominance case involving allegations of excessive pricing), the Tribunal boldly proclaimed that, although its power to impose structural remedies in cases of abuse of dominance may be limited, "a proven allegation of excessive pricing is one of the few instances in which we are empowered to impose structural remedies in the case of a first offence". ${ }^{156}$ The Tribunal outlined that the appropriate approach to resolving a case of this nature was to ask two questions: whether the structure of the market in question enabled firms in that market to charge excessive prices; and whether Mittal SA engaged in conduct designed to take advantage of or abuse the structure of the

144 United States $v$ AT\&T supra par IV of the judgment, 160-165.

145 United States $v$ AT\&T supra par IV of the judgment, 163 and 165. See also Shelanski and Sidak "Antitrust Divestiture in Network Industries" 200168 University of Chicago Law Review 1 .

146 United States $v$ AT\& $T$ supra 163.

147 Ibid.

148 United States $v$ AT\&T supra 165.

14987 F. Supp. 2d 30 (D.D.C. 2000)

150 United States v Microsoft Corp., 97 F. Supp. 2d 59, (D.D.C. 2000).

151 United States v Microsoft Corp., 97 F. Supp. 2d 59, (D.D.C. 2000) 64-65.

152 United States v Microsoft Corp 253 F. 3d 34 (D.C. Cir. 2001) 119.

153 Litan and Nordhaus "Effective Structural Relief in U.S. v. Microsoft" (2000) https://www.brookings.edu/wp-content/uploads/2016/06/05_microsoft_litan.pdf (accessed 2020-04-09).

154 Litan and Nordhaus https://www.brookings.edu/wp-content/uploads/2016/06/05 microsoft litan.pdf 2.

155 (13/CR/FEB04).

156 Harmony Gold Mining Company Ltd v Mittal Steel South Africa Ltd supra par 82. 
market. ${ }^{157}$ The Tribunal then concluded that, "if both questions are answered in the affirmative, the excessive pricing must be proscribed, by imposing a remedy which addresses the underlying structural basis for the excessive price". ${ }^{158}$ It is clear from the language of the Tribunal in the above-quoted passages, that the remedy it was referring to was a divestiture. ${ }^{159}$ However, the Tribunal did not order divestiture in this case because it felt there were other adequate remedies available under the Act that it could still use effectively. ${ }^{160}$ The Tribunal's decision was eventually overturned by the Competition Appeal Court on appeal. ${ }^{161}$

Perhaps the most notable case in South African competition law in which divestiture was considered a suitable remedy in a non-merger case is Competition Commission $v$ Sasol Chemical Industries Ltd. ${ }^{162}$ Here, the Tribunal ordered divestiture of a significant part of the assets of the offending firm, Sasol Chemical Industries, as part of a remedial plan to prevent future abuse of dominance from occurring. This case is significant, it is submitted, in that it marked the first time that the South African Competition Tribunal ordered divestiture in an abuse of dominance case. ${ }^{163}$

\section{OBSERVATIONS AND CONCLUSIONS}

We often hear that South Africa is among countries with an ability to develop what may be considered the "best policies in the world". But we are certainly not known for being adept at implementing our own policies. Competition policy and law in South Africa arose primarily as part of a government plan to address the problems of monopolies and industrial concentration. The policy paper that preceded the adoption of the Competition Act, ${ }^{164}$ and the preamble to the Act itself, explicitly identify economic concentration and the ownership profile in the economy as among the main ills the Act is meant to cure. Some of the most important substantive provisions of the Act, such as those dealing with the abuse of a dominant position, are of significant relevance and importance to concentrated markets.

The Act also empowers competition authorities, in appropriate circumstances, to make use of different remedies available under the Act to redress infringements of the Act and to ensure the achievement of the objectives of the Act. Among such remedies is divestiture. The article observes that while South African competition authorities have used divestiture in merger cases, the remedy is almost never used in cases of abuse of dominance. This may have to do with perceptions around divestiture as a remedy. It is considered drastic, risky and market-unfriendly.

157 Harmony Gold Mining Company Ltd v Mittal Steel South Africa Ltd supra par 84.

158 lbid.

159 Harmony Gold Mining Company Ltd v Mittal Steel South Africa Ltd supra par 217.

160 Harmony Gold Mining Company Ltd v Mittal Steel South Africa Ltd supra par 218.

161 Mittal Steel South Africa Limited v Harmony Gold Mining Company Limited (70/CAC/Apr07) [2009] ZACAC 1.

162 (45/CR/May06, 31/CR/May05) [2010] ZACT 48.

163 Maree A Comparative Appraisal of the Application of Divestiture as a Remedy Under the South African Competition Act (masters dissertation, University of Pretoria) 201718.

164 See Department of Trade and Industry A Framework for Competition, Competitiveness and Development (1997). 
This article argues that divestiture can be an important and effective remedy in non-merger cases, especially in abuse of dominance cases in concentrated markets. The view that divestiture is risky, market-unfriendly and possibly unconstitutional is not consistent with existing legal and economic reality. The legal reality is that divestiture is already a popular remedy that is used extensively in merger cases in many competition jurisdictions around the world. Concerns about the safety, suitability and constitutionality of divestiture as a remedy in non-merger cases appear ill considered, especially when such concerns are not equally raised when the remedy is used in merger cases. Divestiture is divestiture, whether it is used in merger cases or cases of abuse of dominance. Divesture does not change its character or effect depending on the type of transaction or conduct to which it is applied. On the contrary, it has the same effect in the market regardless of the type of setting in which it is applied. It beneficially alters the structure of the market and eliminates the ability of one or a few firms to use market power anticompetitively.

Economically, the argument for the use of divestiture as a competition-law remedy in non-merger cases in South Africa could not be stronger. The structure of the South African economy exhibits all the traits of an economy ripe for the divestiture remedy. The concentrated nature of many markets in the South African economy cannot be overemphasised. In this context, the United States can be a useful model as to the use of divestiture to redress anticompetitive unilateral practices in concentrated markets. When the American economy was confronted with the problem of monopoly and concentration, competition law, in particular the Sherman Act, was adopted and used effectively to address the problem. American competition authorities and the courts were willing to use the remedy of divestiture to break up monopolies. Perhaps the answer to the question whether the Competition Act, bolstered by recent amendments brought into effect by the 2018 Competition Amendment Act, will be successful in addressing the problem of concentration in the South African economy will depend on the willingness of competition authorities and the courts to use the remedy of divestiture, especially in non-merger cases. 